\title{
The Effect of Elevated Temperature on the Lightweight Aggregate Concrete
}

\author{
Rahel Khalid Ibrahim \\ Department of Civil Engineering, \\ Faculty of Engineering, \\ Koya University, \\ University Park, Kurdistan Region of Iraq \\ rahel.khalid@koyauniversity.org
}

\begin{abstract}
The use of lightweight concrete has become widely spread in concrete structures in the last years. Fire can be considered as a destructive hazard that attack concrete structures. In this research the effect of elevated temperature on lightweight aggregate concretes is studied. For this purpose, 81 cube shaped specimens were prepared from three different lightweight aggregate concrete mixes. After moist curing periods for 3, 7 and 28 days, the specimens were subjected to ambient and elevated temperatures of $450^{\circ} \mathrm{C}$ and $650^{\circ} \mathrm{C}$ for $2 \mathrm{hrs}$. The weight of the specimens before and after exposure to elevated temperatures was determined and the residual strength results for the specimens were compared. The results showed that, the elevated temperature induces a decrease in strength and significant weight losses in lightweight aggregate concrete.
\end{abstract}

Keywords: Lightweight aggregate concrete, elevated temperature, compressive strength, residual strength, weight loss

\section{INTRODUCTION}

Lightweight aggregate concrete was first presented by the Romans in the Mediterranean region 2000 years ago where 'The Roman temple Pantheon, Port of Cosa and the Coliseom have been built using lightweight aggregate [1]. From there on, the use of lightweight concrete has been widely spread across other countries such as USA, United Kingdom, Sweden and Malaysia.

The main specialties of lightweight concrete are its low density and thermal conductivity. Its advantages are; that there is a reduction of dead load, faster building rates in construction, and lower transport and handling costs. The building of 'The Pantheon' of lightweight concrete material is still standing eminently in Rome until now for about 18 centuries, shows that the lighter materials can be used in concrete construction and brings many economical advantage [2].

The lightweight aggregates that are used for producing lightweight concrete can be natural aggregate such as pumice, scoria and all of those of volcanic origin and the artificial aggregate such as expanded blast-furnace slag, vermiculite and clinker aggregate [3].
Fire causes real defects in the structures, exposing concrete to elevated temperature results in a loss in strength and occurrence of cracking. Elevated temperature weakens the bond between cement paste and aggregate, and breakdown of the cement gel structure which leads to the consequent loss in the load bearing capacity, increased tendency of drying shrinkage and structural cracking $[4,5]$. Strength deterioration of concrete exposed to elevated temperature may be due to several factors: temperature level, rate of heating, heating time, cooling method, applied load, type of aggregate, type of mineral admixture and air humidity [6-8]. Therefore, there are broadly variable results regarding the exposure of concrete to elevated temperature [9].

A number of studies have shown that an increase in temperature in cement pastes causes the release of physically absorbed water, chemically bonded water and the decomposition of hydration products [10,11]. A wellhydrated cement paste generally consists of calcium silicate hydrate, calcium hydroxide and calcium sulphate aluminate hydrate. A saturated paste also contains a large amount of free water, capillary water and gel water (chemically bonded water). When concrete is heated to $300^{\circ} \mathrm{C}$, the free water and some of the chemically bonded water of hydration products are lost. Exposure to $500^{\circ} \mathrm{C}$ results in further dehydration due to the decomposition of calcium hydroxide. A complete decomposition of calcium silicate hydrate occurs at temperatures beyond $900^{\circ} \mathrm{C}$ [12]. Lightweight concrete is more fire resistant than ordinary normal weight concrete because of its lower thermal conductivity, lower coefficient of thermal expansion and the inherent fire stability of lightweight aggregate. Exposing to elevated temperatures up to $800^{\circ} \mathrm{C}$ induces in a sharp drop of compressive strength for lightweight concrete made with fly ash and lightweight aggregate [13].

Due to its widely usage in construction sector in the last years, investigating the behavior of lightweight aggregate concrete after exposure to elevated temperature is of 
prodigious importance. The main objective for this research is determining the residual strength for lightweight aggregate concrete after exposure to elevated temperatures of $450^{\circ} \mathrm{C}$ and $650^{\circ} \mathrm{C}$.

\section{MATERIALS AND METHODS}

In this research, Ordinary Portland cement (Type I) obtained from Mass Company was used. The fine aggregate (crushed Leca), passed from sieve $4.75 \mathrm{~mm}$, having the fineness modulus of 2.7 and specific gravity of 1.3 was used. The used coarse aggregate was Leca having the maximum size of $12 \mathrm{~mm}$ and the specific gravity of 1.087 .
Three different lightweight aggregate concrete mixes $\mathrm{C}$, $\mathrm{C} 2$ and $\mathrm{C} 3$ were prepared. The mix proportions, by weight, per one meter cube of lightweight concrete are shown in Table 1. The slump test was performed to determine the consistency for the mixes. The density for $\mathrm{C} 1, \mathrm{C} 2$ and $\mathrm{C} 3$ mixes was 1315,1350 and $1370 \mathrm{Kg} / \mathrm{m}^{3}$ respectively. From each mix $27(100 * 100)$ cubes were casted. The specimens were moist cured for 3, 7 and 28 days in a water tank. After curing, the specimens were taken out from the water tank, surface dried and exposed to elevated temperatures of $450^{\circ} \mathrm{C}$ and $650^{\circ} \mathrm{C}$ for $2 \mathrm{hrs}$. by using an electrical oven. The heated specimens were cooled to room temperature and subjected to compression test, beside the non-heated control specimens. The weight of the specimens before and after exposure to elevated temperature was determined.

Table 1 Mix proportions per one meter cube of concrete

\begin{tabular}{|c|c|c|c|c|c|c|}
\hline Mix. & $\begin{array}{c}\text { Cement } \\
\text { Kg. }\end{array}$ & $\begin{array}{c}\text { Gravel } \\
\text { Kg. }\end{array}$ & $\begin{array}{c}\text { Sand } \\
\text { Kg. }\end{array}$ & $\begin{array}{c}\text { Water } \\
\mathbf{~ K g . ~}\end{array}$ & $\begin{array}{c}\text { Concrete Density } \\
\mathbf{K g} / \mathbf{m}^{\mathbf{3}}\end{array}$ & $\begin{array}{c}\text { Slump } \\
\mathbf{~ m m}\end{array}$ \\
\hline $\mathbf{C 1}$ & 370 & 465 & 280 & 200 & 1315 & 70 \\
\hline $\mathbf{C 2}$ & 340 & 520 & 300 & 190 & 1350 & 60 \\
\hline $\mathbf{C 3}$ & 320 & 550 & 290 & 210 & 1370 & 60 \\
\hline
\end{tabular}

\section{RESULTS AND DISCUSSION}

\subsection{Compressive strength}

The compressive strength and relative compressive strength results for all of the specimens are given in Table 2 and Fig. 1. For relative compressive strength, the average compressive strength of 28 day moist cured non-heated specimens' for each concrete mix was taken as $100 \%$ (control specimen) and the compressive strength for the specimens was determined relating to this percentage.

\subsubsection{Compressive strength at ambient temperature $\left(\mathbf{2 6}^{\circ} \mathrm{C}\right)$}

Before exposure to elevated temperature the compressive strength for 3 days moist cured C1, C2 and C3 lightweight aggregate concretes were $6.82,5.68$ and $5.1 \mathrm{MPa}$ respectively. For 3 day moist cured $\mathrm{C} 1, \mathrm{C} 2$ and $\mathrm{C} 3$ specimens the compressive strength was in the percentages of 69,63 and $60 \%$ respectively when they related to control 28 day moist cured specimens. The strength was increased by increasing moist curing periods to become 9.89, 8.95 and 8.5 MPa for 28 day moist cured C1, C2 and C3 concrete specimens respectively. The higher recorded strength for $\mathrm{C} 1$ concrete is due to its higher cement content, and higher consistency which made the concrete to be more compacted when compared with the other lightweight aggregate concretes.

\subsubsection{Compressive strength after exposure to $450^{\circ} \mathrm{C}$}

The exposure to $450^{\circ} \mathrm{C}$ resulted in a strength reduction for all 7 and 28 day cured specimens in different ranges. Slight or no decrease in compressive strength for 3 days moist cured specimens was recorded when compared to 7 and 28 day cured specimens once they related to their strengths before exposure to elevated temperature. The relative strength rates for 3 days specimens remains approximately around 69,61 and $61 \%$, of the 28 day control specimens, for $\mathrm{C} 1, \mathrm{C} 2$ and $\mathrm{C} 3$ specimens respectively before and after exposure to $450^{\circ} \mathrm{C}$. Early age concrete specimens contain a reasonable amount of non-hydrated cement particles which by the presence of heat and moisture get hydrated to produce high amounts of calcium silicate hydrate that is responsible for the strength of concrete which by turn made the early age lightweight aggregate concrete specimens to show higher residual strength. The lower residual strength for later age specimens is due to the deterioration for the binder material after exposure to $450^{\circ} \mathrm{C}$.

\subsubsection{Compressive strength after exposure to $650^{\circ} \mathrm{C}$} The exposure to $650^{\circ} \mathrm{C}$ caused a dramatic reduction in compressive strength for all specimens. The residual strength for 28 day moist cured lightweight aggregate concrete specimens was around 58 to $59 \%$ of their original strengths before exposure to $650^{\circ} \mathrm{C}$. When the comparison is made within the curing age for each group of the specimens, once again the early age specimens showed higher residual strength than the later age specimens. 
Table 2The compressive strength results for the specimens

\begin{tabular}{|c|c|c|c|c|c|c|c|c|c|}
\hline \multicolumn{10}{|c|}{ Compressive strength for different curing periods after exposure to different temperatures (MPa) } \\
\hline & \multicolumn{3}{|c|}{$\mathrm{C1}$} & \multicolumn{3}{|c|}{$\mathrm{C2}$} & \multicolumn{3}{|c|}{ C3 } \\
\hline & 3Day & 7day & 28day & 3Day & 7day & 28day & 3Day & 7day & 28day \\
\hline $26^{\circ} \mathrm{C}$ & 6.820 & 7.563 & 9.893 & 5.680 & 6.727 & 8.947 & 5.120 & 6.150 & 8.547 \\
\hline $450^{\circ} \mathrm{C}$ & 6.813 & 6.203 & 7.607 & 5.427 & 5.207 & 7.267 & 5.200 & 5.000 & 7.547 \\
\hline $650^{\circ} \mathrm{C}$ & 6.430 & 5.993 & 5.790 & 4.440 & 4.600 & 5.177 & 4.053 & 4.500 & 5.033 \\
\hline
\end{tabular}

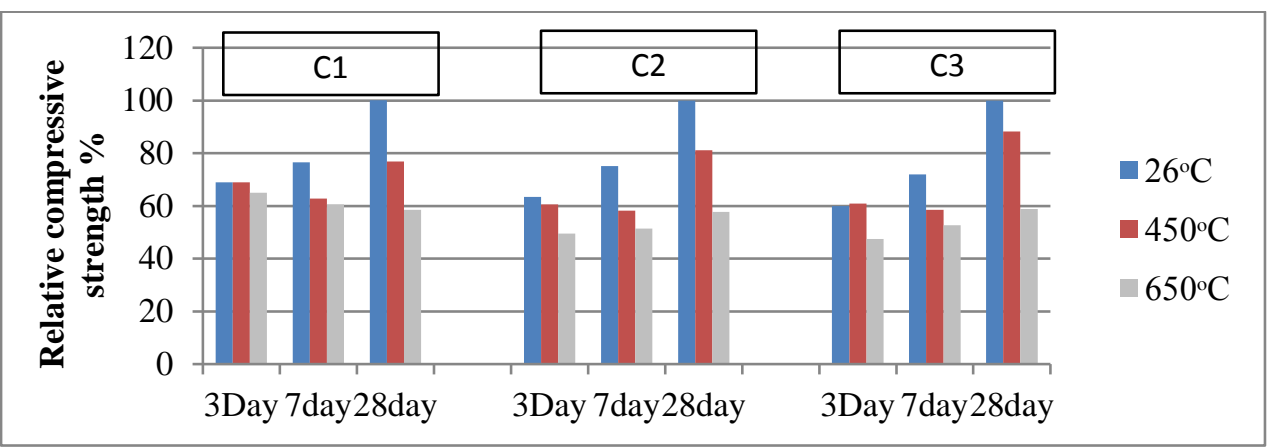

Fig. 1 Relative compressive strength for $\mathrm{C} 1, \mathrm{C} 2$ and $\mathrm{C} 3$ concrete before and after exposure to elevated temperatures at different moist curing periods

\subsection{Weight loss}

The relative weight loss for the specimens upon exposing to elevated temperatures of $450^{\circ} \mathrm{C}$ and $650^{\circ} \mathrm{C}$ is given in Fig. 2. For determining the relative weight loss, the average weight for the specimens before exposure to elevated temperature was accounted as $100 \%$. Then the relative weight for the specimens after exposure to elevated temperature was calculated according to this rate and subtracted from 100 .

From Fig. 2 it can be seen that by elevating the exposure temperature from $450^{\circ} \mathrm{C}$ to $650^{\circ} \mathrm{C}$, the weight loss of the specimens increased at all curing periods and for all three lightweight aggregate concretes. This phenomenon is due to the higher degradation of the binder material (calcium silicate hydrate) at $650^{\circ} \mathrm{C}$ by losing a part of the chemically bonded water which the reduction in compressive strength at this temperature is related to. The higher loss in the weight of the specimens after exposure to high temperature indicates higher loss in compressive strength.

The 3 day moist cured specimens showed lower weight loss than 7 and 28 days moist cured specimens after exposure to elevated temperatures of $450^{\circ} \mathrm{C}$ and $650^{\circ} \mathrm{C}$. This behavior is mostly due to the participation of heat and moisture in accelerating the hydration process of nonhydrated cement particles in this early age for producing further binder material.

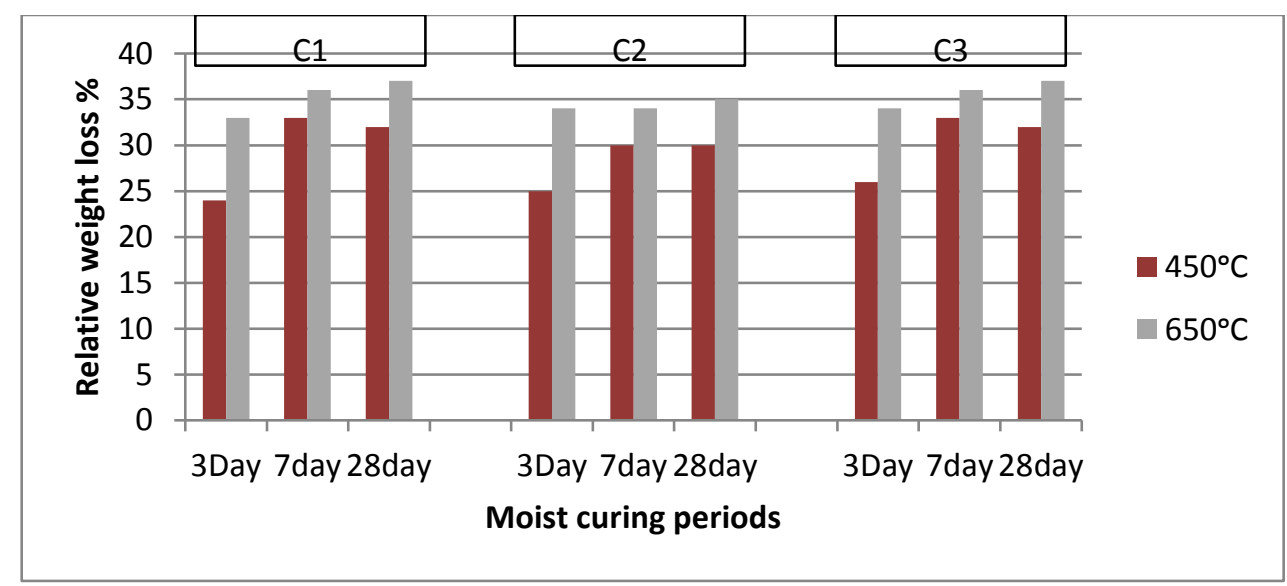

Fig. 2 Weight loss for lightweight aggregate concrete specimens after exposure to $450^{\circ} \mathrm{C}$ and 650 


\section{CONCLUSIONS}

The following conclusions are drawn from this research:

- 28 day moist cured lightweight aggregate concrete loses 12 to $23 \%$ of their compressive strength after exposure to $450^{\circ} \mathrm{C}$.

- The residual strength for 28 day moist cured lightweight aggregate concrete is around 58 to $59 \%$ of their original strength after exposure to $650^{\circ} \mathrm{C}$.

- The residual strength after exposure to elevated temperatures at early ages is higher than the later ages for each age group of the specimens.

- Lightweight aggregate concrete loses 24 to $37 \%$ of its weight after exposure to elevated temperatures of $450^{\circ} \mathrm{C}$ and $650^{\circ} \mathrm{C}$.

- The higher exposure temperature related to the higher weight loss.

- The higher loss in the weight of the specimens after exposure to high temperature indicates higher loss in compressive strength.

\section{REFERENCES}

[1] ACI, ACI 213R-03, Guide for Structural Lightweight-Aggregate Concrete, ACI, Michigan USA, 2003, p. 38.

[2] L.B. Satish Chandra, Light Weight Aggregate Concrete Science, Technology and Applications, Noyas Publication, Norwich, USA, 2002.

[3] S.K. Duggal, Building materials, New Age International2009.

[4] G. Khoury, Compressive strength of concrete at high temperatures: a reassessment, Magazine of Concrete Research 44(161) (1992) 291-309.

[5] S. Handoo, S. Agarwal, S. Agarwal, Physicochemical, mineralogical, and morphological characteristics of concrete exposed to elevated temperatures, Cement and Concrete Research 32(7) (2002) 10091018.

[6] G.A. Khoury, Effect of fire on concrete and concrete structures, Progress in Structural Engineering and Materials 2(4) (2000) 429447.

[7] A. Lau, M. Anson, Effect of high temperatures on high performance steel fibre reinforced concrete, Cement and Concrete Research 36(9) (2006) 1698-1707.

[8] A.F. Bingöl, R. Gül, Effect of elevated temperatures and cooling regimes on normal strength concrete, Fire and Materials 33(2) (2009) 79-88.

[9] A.M. Neville, Properties of Concrete, Pearson 2005.

[10]G. Ye, X. Liu, G. De Schutter, L. Taerwe, P. Vandevelde, Phase distribution and microstructural changes of self-compacting cement paste at elevated temperature, Cement and Concrete Research 37(6) (2007) 978-987.

[11]R.K. Ibrahim, R. Hamid, M.R. Taha, Strength and Microstructure of Mortar Containing Nanosilica at High Temperature, ACI Materials Journal 111(2) (2014).

[12]P. Klieger, J. Lamond, Significance of tests and properties of concrete and concretemaking materials, ASTM International1994.

[13]H. Tanyildizi, A. Coskun, The effect of high temperature on compressive strength and splitting tensile strength of structural lightweight concrete containing fly ash, Construction and building materials 22(11) (2008) 2269-2275.

\section{Biography}

Rahel Khalid Ibrahim was born in Erbil/Iraqi Kurdistan in 1973. He got his; BSc degree from Civil Engineering departmen/Salahaddin University in 1996, MSc from department of Civil engineering/EGE university Izmir/Turkey in 2001 and $\mathrm{PhD}$ degree from the department of Civil and Structural Engineering/University Kebangsaan Malaysia in 2013. Currently he is Director of Research Center and lecturer at Civil Engineering Department Faculty of Engineering Koya University. His Google scholars cite is as following:

https://scholar.google.com/citations?hl=en\&imq=Rahel+K halid+Ibrahim\&user=aX-tyR0AAAAJ 